\title{
Isolation and purification of Aeromonas sobria cytotonic enterotoxin and $\beta$-haemolysin
}

\author{
P. J. GOSLING, P. C. B. TURNBULL*, N. F. LIGHTFOOT†, J. V. S. PETHER and R. J. LEWIS $\ddagger$ \\ Public Health Laboratory, Musgrove Park Hospital, Taunton, Somerset TA1 5DB, P PHS Centre for Applied \\ Microbiology and Research, Division of Biologics, Porton Down, Salisbury, Wiltshire SP4 OJG, † Public Health \\ Laboratory, General Hospital, Westgate Road, Newcastle upon Tyne NE4 6BE and $\ddagger$ Faculty of Applied Sciences, \\ University of the West of England, Frenchay, Bristol BS16 $10 \mathrm{Y}$
}

\begin{abstract}
Summary. Aeromonas sp., grown in tryptone soya broth supplemented with yeast extract, $0.6 \%, \mathrm{pH} 7.5$, and incubated with agitation at 100 oscillations/min for $15 \mathrm{~h}$ at $37^{\circ} \mathrm{C}$ produced optimal amounts of $\beta$-haemolysin and cytotonic enterotoxin. More prolonged incubation resulted in the loss of enterotoxic activity and anion exchange chromatographic analysis indicated the presence of a moiety capable of breaking down the toxin. Anion exchange fast protein liquid chromatography resulted in a single peak of haemolytic activity and two peaks with enterotoxic activitiy. The cytotonic enterotoxin was purified from the fraction most active in the infant mouse assay; the second peak, which did not cross-react immunologically, may represent a second cytotonic enterotoxin. Neither peak was observed in the chromatographic fractions of filtrates from strains devoid of activity in the infant mouse assay. Purified enterotoxin, estimated to have a mol. wt of $15 \mathrm{kDa}$ by SDS-PAGE, caused fluid accumulation in the infant mouse assay, was non-haemolytic to rabbit erythrocytes, caused an increase in cAMP activity in tissue culture cells and did not cross-react immunologically with components of cholera toxin or the whole toxin. Purified $\beta$-haemolysin had an estimated mol. wt of $55 \mathrm{kDa}$, lysed rabbit erythrocytes and did not cause fluid accumulation in the infant mouse test.
\end{abstract}

\section{Introduction}

Motile Aeromonas spp. have been incriminated as aetiological agents of diarrhoeal disease in man for two decades. ${ }^{1-4}$ Isolates of motile aeromonads from human faeces have been associated significantly with symptoms of gastroenteritis, ${ }^{5}$ shown to produce extracellular products that elicit an enterotoxic response in the infant mouse assay ${ }^{6}$ and to produce adhesins to human intestinal cells. ${ }^{7}$ However, attempts to fulfil Koch's postulates by reproducing the disease in animal models, or even in man, have been unsuccessful. ${ }^{8}$

To evaluate the potential of Aeromonas spp. as enteropathogens, a better understanding of their pathogenesis is necessary. Progress has been hampered by confusion in the taxonomy of the genus and by the complex extracellular protein profile of members of the genus. The biologically active proteins produced by motile aeromonads include haemolysins and at least one enterotoxin that are considered to be potential virulence factors in Aeromonas-associated diarrhoeal disease.

In previous studies on Aeromonas enterotoxin, ${ }^{8}$ crude preparations have been used and attempts to assess their role as virulence factors have been com- plicated by the presence of other extracellular products. It remains unclear whether there is one or more Aeromonas enterotoxins, whether the toxin is cytotoxic, i.e. causing tissue damage, cytotonic, i.e. exerting an enterotoxic effect without tissue damage, or if it cross-reacts immunologically with cholera toxin.

The aims of the present study were to establish the optimum conditions for enterotoxin production, and hence detection of enterotoxigenic strains, and to separate and purify aeromonas enterotoxin and haemolysin to clarify their roles as virulence factors in disease in man.

\section{Materials and methods}

\section{Bacterial strains}

Two strains of Aeromonas spp. (VL8509 and VL8804) shown previously to produce haemolysin and enterotoxin, ${ }^{9}$ and two strains (VL7711 and VL8778) shown to be devoid of these activities, were kindly supplied by Dr J. V. Lee, PHLS Centre for Applied Microbiology and Research, Porton Down, Wiltshire. Strains were maintained on Nutrient Agar slopes overlaid with sterile oil at room temperature and in 
Nutrient Broth (Unipath) containing glycerol $20 \%$ at $-70^{\circ} \mathrm{C}$.

\section{Preparation of cell-free culture filtrates $(C F C F)$}

Fresh subcultures of Aeromonas strains on nutrient agar were used to inoculate $10 \mathrm{ml}$ of tryptone soya broth (Unipath) supplemented with yeast extract $0.6 \%$ in 100-ml conical flasks which were incubated in a flask shaker at various times and temperatures. Cultures were then centrifuged at $10000 \mathrm{~g}$ for $10 \mathrm{~min}$ at $4^{\circ} \mathrm{C}$ and the supernate was filtered through a $0 \cdot 22-\mu \mathrm{m}$ low protein binding membrane filter (Sartorius $\mathrm{GmbH}$, Germany). CFCF were stored at $-70^{\circ} \mathrm{C}$. To establish parameters during toxin production that could affect detection of enterotoxigenic strains, experiments varying the $\mathrm{pH}$, agitation rate, time and temperature of growth were conducted. Growth curves were constructed from viable counts obtained by a standardised drop count method ${ }^{10}$ at timed intervals.

\section{Concentration of $C F C F$}

To facilitate detection of enterotoxic activity the CFCF were concentrated 20 -fold by ultrafiltration through an Amicon PM series filter apparatus (Amicon, Basingstoke) with a Diaflo membrane PM10 having a $10-\mathrm{kDa}$ cut off. Ultrafiltration was performed in an ice bath.

\section{Enterotoxin assay}

Enterotoxic activity was determined in infant mice. The mice were inoculated by intraperitoneal injection with $0.1 \mathrm{ml}$ of CFCF to which Evans blue $2 \%$ solution had been added ( $10 \mu \mathrm{l}$ in $1 \mathrm{ml}$ of CFCF). Each test involved two to five mice and the intestinal weight/ body weight (IW/BW) ratio was determined at $3 \mathrm{~h} \pm$ $10 \mathrm{~min}$. An IW/BW ratio of $>0.8$ was considered to indicate enterotoxic activity.

\section{Haemolysin assay}

Doubling dilutions of unconcentrated CFCF in normal saline, or of fractions following FPLC separations, were made and $100-\mu 1$ volumes were added to equal volumes of a suspension of rabbit erythrocytes $0.8 \%$ in normal saline in 96-well round-bottomed trays. Haemolysis was recorded after incubation for $1 \mathrm{~h}$ at $37^{\circ} \mathrm{C}$ and then after subsequent incubation for $2 \mathrm{~h}$ at $4^{\circ} \mathrm{C}$. The highest dilution giving complete haemolysis was taken as the end point.

\section{Protein determination}

Protein was measured by the Folin-Lowry method and with a protein assay kit (BioRad) with bovine serum albumin as a standard.

\section{Chromatography methods}

A fast protein liquid chromatography (FPLC, Pharmacia, Milton Keynes) apparatus was used.

Anion exchange chromatography was performed on a pre-packed Mono Q column HR 5/5 (Pharmacia). Buffer A consisted of $30 \mathrm{~mm}$ triethanolamine buffer, $\mathrm{pH} 8$, and buffer $\mathrm{B}$ of $30 \mathrm{~mm}$ triethanolamine buffer, $\mathrm{pH} 8$, containing $1 \mathrm{M} \mathrm{NaCl}$. All reagents were of analytical grade and all buffers and solutions were pre-filtered through a $0 \cdot 22-\mu \mathrm{m}$ filter before use. Various elution programmes were constructed to vary the linear gradient rate from 0 to $100 \%$ buffer B with a flow rate of $1 \mathrm{ml} / \mathrm{min}$. The protein content of the eluate was monitored at $280 \mathrm{~nm}$ and all fractions over the course of the gradient were collected.

Gel filtration was performed on a pre-packed column HR 10/30 (Pharmacia) containing $24 \mathrm{ml}$ of Superose 12. The elution buffer consisted of $0.05 \mathrm{M}$ $\mathrm{NaH}_{2} \mathrm{PO}_{4}, \mathrm{pH} 7 \cdot 0$, containing $0.15 \mathrm{M} \mathrm{NaCl}$ and the flow rate was $0.5 \mathrm{ml} / \mathrm{min}$. The protein content of the eluate was monitored at $280 \mathrm{~nm}$ and all fractions were collected throughout the separation. Immediately after separation, with the same elution buffer, mol. wt standards were applied to the column and the elution times were noted. The standards consisted of bovine serum albumin $(67 \mathrm{kDa})$, ovalbumin $(43 \mathrm{kDa})$, chymotrypsinogen $(25 \mathrm{kDa})$ and ribonuclease (13.7 kDa) (Sigma).

\section{Scale-up of production and purification of Aeromonas} toxins

Batches of CFCF $(250 \mathrm{ml})$ were pooled until $2 \mathrm{~L}$ was available. This was diluted four-fold with $30 \mathrm{~mm}$ triethanolamine buffer containing $1 \mathrm{~mm}$ EDTA, pH 8.0 (buffer C), and an anion exchange resin (Q Sepharose Fast Flow, Pharmacia) was added and kept suspended for $1 \mathrm{~h}$ at $4^{\circ} \mathrm{C}$. This was then allowed to settle at $4^{\circ} \mathrm{C}$ and the resin was collected in a large diameter chromatography column. The resin was then washed with three bed volumes of pre-cooled buffer C. Protein was eluted from the resin with three bed volumes of buffer $\mathrm{C}$ containing $0.23 \mathrm{M} \mathrm{NaCl}$ at $4^{\circ} \mathrm{C}$. Three sequential protein elutions from the resin were performed by washing with three bed volumes of buffer $\mathrm{C}$ containing $0.23 \mathrm{M}, 0.48 \mathrm{M}$ and $1 \mathrm{M} \mathrm{NaCl}$ respectively. The products were collected and stored at $-70^{\circ} \mathrm{C}$. Subsequently they were subjected separately to precipitation with saturated ammonium sulphate $70 \%$ and the precipitate was collected by centrifugation at $23000 \mathrm{~g}$. This was re-suspended in $2 \mathrm{ml}$ of buffer $\mathrm{C}$ and dialysed at $4^{\circ} \mathrm{C}$ for $5 \mathrm{~h}$ against a large volume of buffer $\mathrm{C}$. Insoluble material was removed by centrifugation at $15000 \mathrm{~g}$ and the fluids were filter sterilised through a $0 \cdot 22-\mu \mathrm{m}$ filter. The preparation originating from the wash-through with $0.23 \mathrm{M} \mathrm{NaCl}$ was regarded as crude aeromonas $\beta$-haemolysin and that originating from the wash-through with $1 \mathrm{M} \mathrm{NaCl}$ as crude aeromonas enterotoxin. The crude toxin 


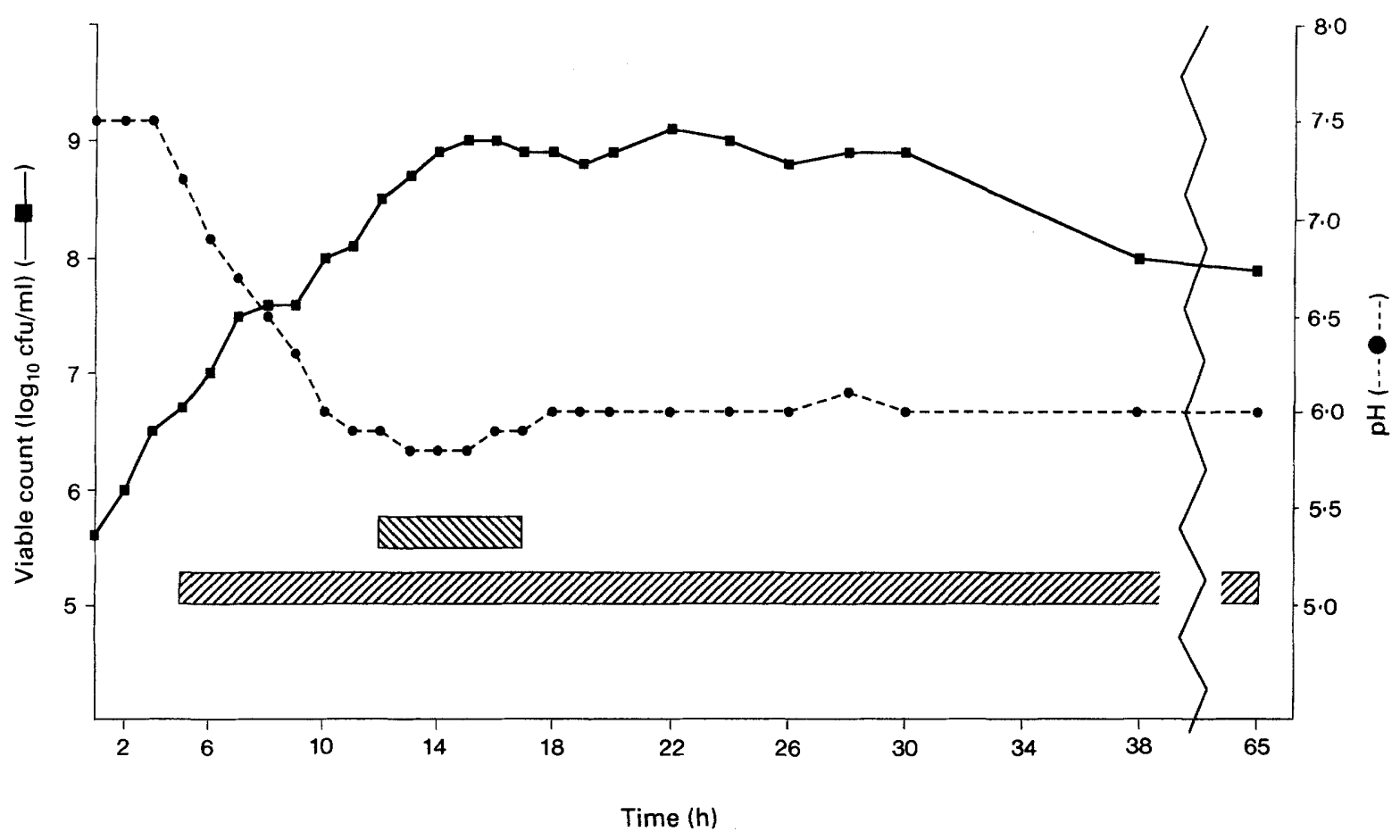

Fig. 1. Haemolytic $(\square)$ and enterotoxic $(\mathbb{Q})$ activity in CFCF of $A$. sobria strain VL8509 sampled during growth in tryptone soya broth supplemented with yeast extract $0.6 \%$.

preparations were purified by application to a prepacked Mono Q HR 16/10 (Pharmacia) anion exchange column and active fractions were collected. Buffer exchange was carried out by ultrafiltration with filters of 10000-kDa cut off (Sartorius) and the active fractions were again subjected to anion exchange chromatography as before. Active fractions were collected, dialysed against phosphate buffered saline (PBS), $\mathrm{pH} 7 \cdot 4$, and the resulting purified toxins were stored at $-70^{\circ} \mathrm{C}$

\section{Gel electrophoresis}

SDS-PAGE was performed as described by Laem$\mathrm{mli}^{11}$ on CFCF samples and purified toxins. Samples in SDS reducing buffer $(0.5 \mathrm{~m}$ Tris- $\mathrm{HCl}, \mathrm{pH} 6.8$, containing SDS $2 \% \mathrm{w} / \mathrm{v}$, glycerol $10 \% \mathrm{v} / \mathrm{v}, 2-$ mercaptoethanol $5 \% \mathrm{v} / \mathrm{v}$ and a trace of bromophenol blue dye) were boiled for $2 \mathrm{~min}$ and applied to a 1.5$\mathrm{mm}$ resolving gel of acrylamide $12 \% \mathrm{w} / \mathrm{v}$ in $375 \mathrm{mM}$ Tris- $\mathrm{HCl}$, $\mathrm{pH} .8 \cdot 8$, containing SDS $0 \cdot 1 \%$ via a stacking gel, used to concentrate samples to improve band resolution, consisting of acrylamide $4 \% \mathrm{w} / \mathrm{v}$ in $125 \mathrm{~mm}$ Tris- $\mathrm{HCl}$, pH 6.8, containing SDS $0 \cdot 1 \% \mathrm{w} / \mathrm{v}$. Rabbit muscle phosphorylase $\mathrm{b}(106 \mathrm{kDa})$, bovine serum albumin $(80 \mathrm{kDa})$, hen egg white ovalbumin $(49.5 \mathrm{kDa})$, bovine carbonic anhydrase $(32.5 \mathrm{kDa})$, soya bean trypsin inhibitor $(27.5 \mathrm{kDa})$ and hen egg white lysozyme $(18.5 \mathrm{kDa})$ were included as mol. wt markers (BioRad).

Electrophoresis with a voltage gradient of $80 \mathrm{~V}$ was performed in $25 \mathrm{~mm}$ Tris- $\mathrm{HCl}$ ( $\mathrm{pH} \mathrm{8.3)} \mathrm{containing}$ $192 \mathrm{~mm}$ glycine and SDS $0.1 \% \mathrm{w} / \mathrm{v}$. Gels were stained overnight with Coomassie Brilliant Blue R250 0.1\% $\mathrm{w} / \mathrm{v}$ in methanol: acetic acid:water $(40: 10: 50)$ and cleared in several changes of the same solvent.

\section{Ganglioside GM1 binding assay}

Ganglioside GM1 (Sigma) $50 \mu \mathrm{g} / \mathrm{ml}$ diluted in carbonate buffer, $\mathrm{pH} 9 \cdot 6$, was added to each well of a 96-well round-bottomed tray. After overnight incubation at $4^{\circ} \mathrm{C}$, the trays were washed three times with $0.1 \mathrm{~m}$ PBS containing Tween $200.5 \%$ (PBST), $\mathrm{pH} 7.4$, and bovine serum albumin $0.1 \%$. The trays were washed once with distilled water and dried. Test solutions $(50 \mu \mathrm{l})$ of crude or purified aeromonas toxins were added to wells and incubated at room temperature overnight. Solutions containing cholera toxin (CT; Sigma), 0.5-500 mg/ml, and uninoculated broth were also included as positive and negative controls, respectively. All solutions were tested in duplicate. After three washes with PBST, goat anti-CT (Calbiochem, Nottingham) and rabbit anti-aeromonas cytotonic enterotoxin at a dilution of 1 in 640 were used to detect bound antigen. Diluted normal rabbit serum, 1 in 10-1 in 1280, was added to duplicate wells treated with test samples to provide negative controls. After overnight incubation at $4^{\circ} \mathrm{C}$, the trays were washed three times with PBST and protein A peroxidase conjugate (Sigma) diluted 1 in 1000 was added to detect bound immunoglobulins.

After incubation for $1 \mathrm{~h}$ at $37^{\circ} \mathrm{C}, 100 \mu \mathrm{l}$ of substrate, 2,2'-azino-di-(3-ethylbenzthiazoline sulphonic acid) (ABTS) was added to each well. Trays were incubated for $30 \mathrm{~min}$ at $37^{\circ} \mathrm{C}$ and the absorbance of wells was read at $A_{410} \mathrm{~nm}$ with a MicroELISA Minireader (Dynatech). Wells were considered to have demon- 

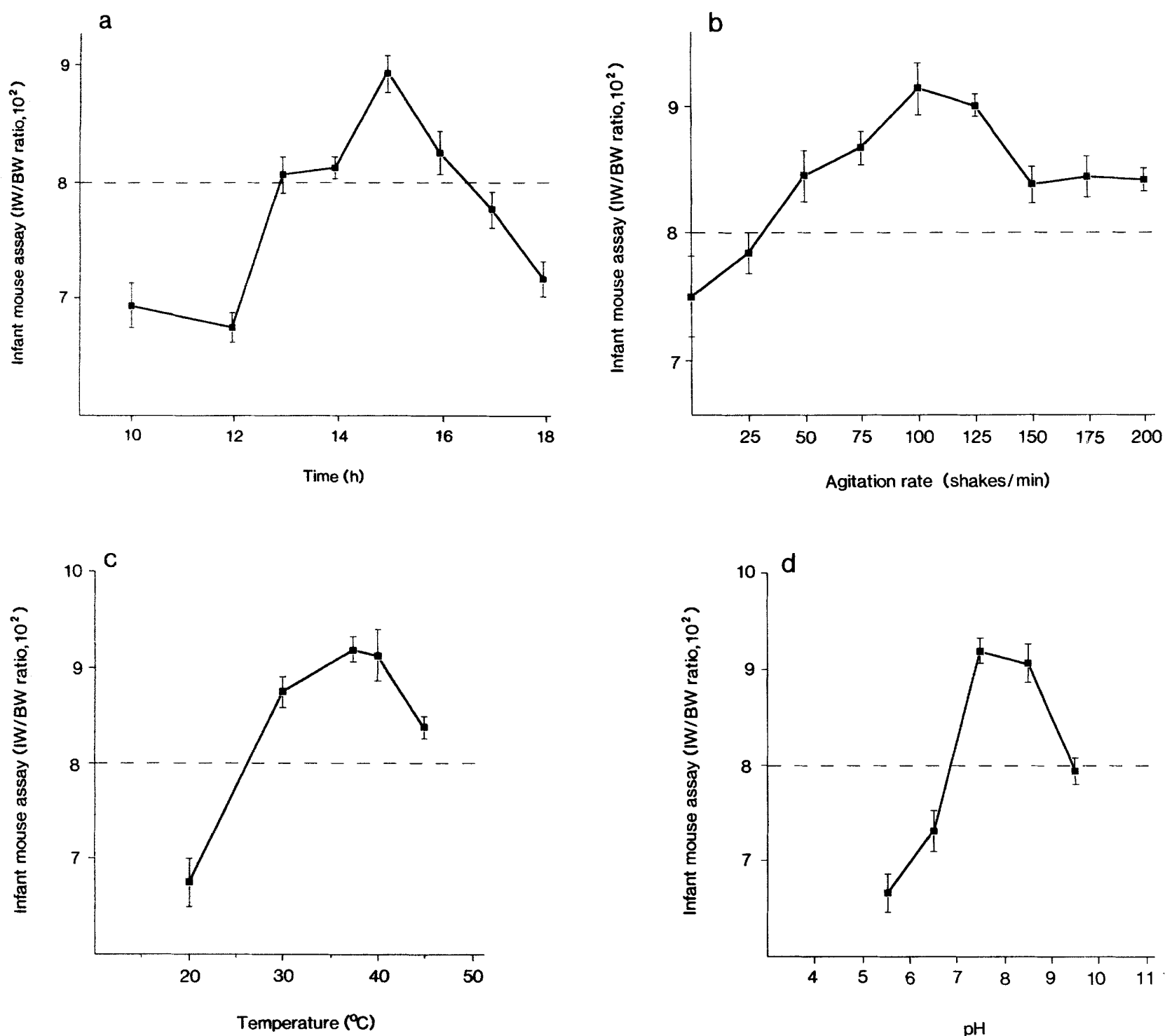

Fig. 2. The effect of (a) duration of incubation, (b) agitation, (c) temperature of incubation and (d) starting pH, of 15 -h cultures of $A$. sobria strain VL8509 in tryptone soya broth supplemented with yeast extract $2 \%$ on the elaboration of enterotoxin. Each result represents a mean value obtained from three mice and vertical lines indicate SD. Intestinal weight/body weight (IW/BW) ratios above the dotted line are considered an enterotoxigenic response.

strated binding to ganglioside $\mathrm{GM} 1$ at an $\mathrm{A}_{\mathbf{4 1 0}}$ reading of $>0 \cdot 1$.

\section{Cyclic AMP determination}

Stimulation of cAMP production in Chinese hamster ovary tissue culture cells treated with crude and purified aeromonas cytotonic enterotoxin was determined. Tissue culture cells were grown for $24 \mathrm{~h}$ in $25-$ $\mathrm{ml}$ flasks, treated with $0.33 \mathrm{ml}$ of the toxin and incubated at $37^{\circ} \mathrm{C}$ overnight. Three flasks were used for each sample and the cells were trypsinised, pooled for each sample, rinsed in PBS, $\mathrm{pH} \mathrm{7,} \mathrm{and} \mathrm{homo-}$ genised in $4 \mathrm{~mm}$ EDTA, $\mathrm{pH}$ 7. Samples were tested in duplicate. The sonicates were boiled for $3 \mathrm{~min}$, centrifuged for $5 \mathrm{~min}$ and the amount of cAMP in $50 \mu \mathrm{l}$ of supernate was determined by radio-immunoassay, kindly carried out by Dr P. J. Wood at the Regional Endocrine Laboratory, Southampton. Cholera toxin at 5 and $50 \mathrm{ng} / \mathrm{ml}$, untreated cells and 20 -fold broth concentrates were used as positive and negative controls, respectively.

\section{Stability of toxins}

Purified toxin (in 0.2-ml volumes) was incubated with trypsin, pronase and papain (Calbiochem, $1.0 \mathrm{mg} / \mathrm{ml}$ ) for $15 \mathrm{~min}$ at room temperature and then tested for activity. Sample volumes were exposed to a range of temperatures $\left(25^{\circ}-80^{\circ} \mathrm{C}\right)$ in glass tubes in a waterbath for 15 or $60 \mathrm{~min}$ and cooled rapidly before testing for remaining haemolytic and enterotoxic activity.

\section{Immunological cross-reactivity test}

Gel immunodiffusion tests were performed in agarose gel (BDH Chemicals Ltd) $1 \% \mathrm{w} / \mathrm{v}$. Purified toxins were tested against specific antisera and antisera to whole cholera toxin, cholera A subunit and cholera B subunit (Calbiochem) in $3 \mathrm{~mm}$ diameter wells. 
Antisera were tested neat and at five- and 50 -fold dilutions in PBS, pH 7.4.

\section{Results}

\section{Production of toxins}

The $\mathrm{pH}$, agitation rate, time and temperature of growth giving optimal toxin yields by strains VL8509 and VL8804 were determined (figs. 1 and 2). Optimum enterotoxigenicity was observed after growth in tryptone soya broth supplemented with yeast extract $0.6 \%$, $\mathrm{pH} 7.5$, for $15 \mathrm{~h}$ at $37^{\circ} \mathrm{C}$ with agitation of 100 oscillations/min. Enterotoxicity became detectable in the

Table I. Mean haemolytic and enterotoxic activity of 20 human faecal isolates after incubation for 15 and $17 \mathrm{~h}$

\begin{tabular}{c|cc}
\hline $\begin{array}{c}\text { Incubation } \\
\text { time } \\
\text { (h) }\end{array}$ & $\begin{array}{c}\text { Haemolytic activity } \\
\text {-mean(SD)HU/ml }\end{array}$ & $\begin{array}{c}\text { Enterotoxic activity } \\
\text { mean(SD)IW/BW ratio }\end{array}$ \\
\hline 15 & $8.2(3.1) \times 10^{2}$ & $\begin{array}{c}8.9(90.4) \times 10^{2} \\
6.8(0.6) \times 10^{2}\end{array}$ \\
17 & $9.2(3.3) \times 10^{2}$ & \\
\hline
\end{tabular}

$\mathrm{HU}$, one haemolytic unit is the dilution that caused complete haemolysis of rabbit erythrocytes.

IW/BW, intestinal weight/body weight ratio.

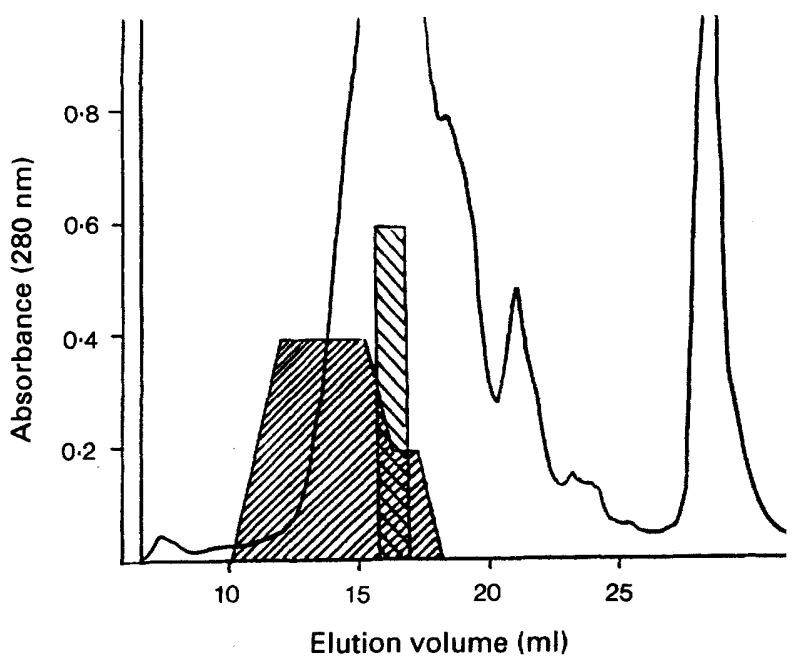

Fig. 3. FPLC gel filtration separation of an enterotoxic CFCF of A. sobria strain VL8509: haemolytic $(\square)$ and enterotoxic $(\mathbb{Q})$ activity.

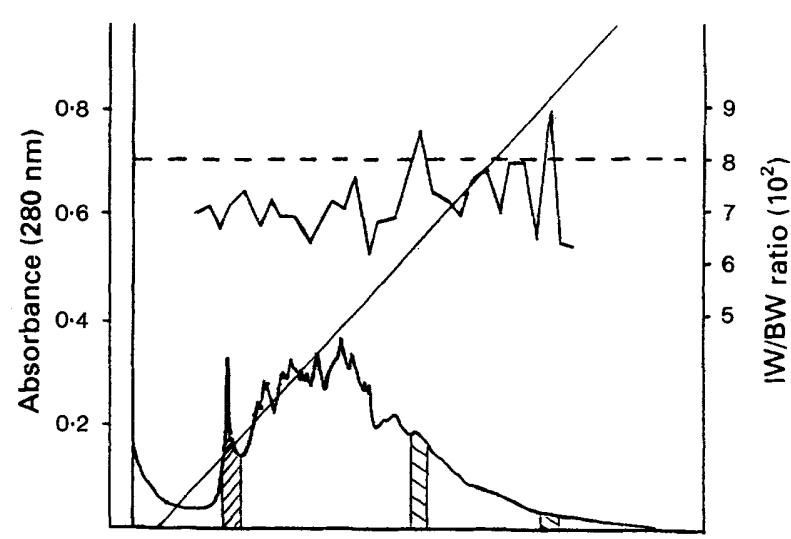

Elution volume $(\mathrm{ml})$

Fig. 4. FPLC anion exchange chromatograph of an enterotoxic CFCF of $A$. sobria strain VL8509: haemolytic ( () ) and enterotoxic $(\mathbb{Q})$ activity.

CFCF during the late logarithmic phase of growth after incubation for $12 \mathrm{~h}$, reaching a peak at $15 \mathrm{~h}$. However, this activity disappeared after $17 \mathrm{~h}$. Haemolytic activity became detectable after $5 \mathrm{~h}$ and remained throughout the experiment, reaching a peak at $19 \mathrm{~h}$.

Confirmation of these results was obtained in tests on the CFCF of 20 human faecal isolates of Aeromonas spp. for haemolytic and enterotoxic activity after incubation for 15 and $17 \mathrm{~h}$ (table I). Enterotoxin was not evident at $12-17 \mathrm{~h}$ and haemolysin was not detected from $5 \mathrm{~h}$ onwards in the CFCF of strains VL7711 and VL8778, which had been included as negative controls on the basis of previous findings. ${ }^{9}$

Anion exchange chromatography of CFCF revealed changing protein profiles with prolonged incubation and subsequent loss of enterotoxigenicity. The lack of haemolytic and enterotoxigenic activity by strains VL7711 and VL8778 was confirmed under all the conditions tested.

\section{Gel filtration}

A large band of proteins was eluted from the Superose 12 HR 10/30 column with 12-20 ml of elution buffer. Haemolytic activity was observed over a band of eight fractions eluted with $10-18 \mathrm{ml}$ of buffer; enterotoxic activity was detected in a single fraction eluted with $17 \mathrm{ml}$ of buffer. The enterotoxic

Table II. Purification of cytotonic enterotoxin from A. sobria strain VL8509

\begin{tabular}{lccccccc}
\hline $\begin{array}{l}\text { Method of } \\
\text { purification }\end{array}$ & $\begin{array}{c}\text { Volume } \\
(\mathrm{ml})\end{array}$ & $\begin{array}{c}\text { Protein } \\
\text { content } \\
(\mathrm{mg} / \mathrm{ml})\end{array}$ & $\begin{array}{c}\text { Enterotoxic } \\
\text { activity } \\
(\mathrm{EU} / \mathrm{ml})\end{array}$ & $\begin{array}{c}\text { Specific } \\
\text { activity } \\
(\mathrm{EU} / \mathrm{mg})\end{array}$ & $\begin{array}{c}\text { Total activity } \\
\left(\mathrm{EU} \times 10^{2}\right)\end{array}$ & $\begin{array}{c}\text { Purifi- } \\
\text { cation } \\
\text { ratio }\end{array}$ & $\begin{array}{c}\text { Yield } \\
(\%)\end{array}$ \\
\hline $\begin{array}{l}\text { Cell-free } \\
\text { culture filtrate }\end{array}$ & 2000 & 4.2 & 40 & 9.5 & 3360 & 1.0 & 100 \\
$\begin{array}{l}\text { Sephadex Fast Flow } \\
\text { (crude toxin) }\end{array}$ & 33 & 5.5 & 1000 & $181 \cdot 8$ & 330 & $19 \cdot 1$ & 9.8 \\
$\begin{array}{l}\text { FPLC Mono Q } \\
\text { anion exchange } \\
\text { chromatography } \\
\text { (purified toxin) }\end{array}$ & $4 \cdot 2$ & $1 \cdot 2$ & 500 & $416 \cdot 7$ & 21 & 43.9 & 0.6 \\
\hline
\end{tabular}


Table III. Purification of haemolysin from A. sobria strain VL8509

\begin{tabular}{|c|c|c|c|c|c|c|c|}
\hline $\begin{array}{l}\text { Method of } \\
\text { purification }\end{array}$ & $\begin{array}{l}\text { Volume } \\
\text { (ml) }\end{array}$ & $\begin{array}{l}\text { Protein } \\
\text { content } \\
(\mathrm{mg} / \mathrm{ml})\end{array}$ & $\begin{array}{c}\text { Haemolytic } \\
\text { activity } \\
(\mathrm{HU} / \mathrm{ml})\end{array}$ & $\begin{array}{l}\text { Specific } \\
\text { activity } \\
(\mathrm{HU} / \mathrm{mg})\end{array}$ & $\begin{array}{c}\text { Total } \\
\text { activity } \\
\left(\mathrm{HU} \times 10^{4}\right)\end{array}$ & $\begin{array}{l}\text { Purifi- } \\
\text { cation } \\
\text { ratio }\end{array}$ & $\begin{array}{l}\text { Yield } \\
(\%)\end{array}$ \\
\hline $\begin{array}{l}\text { Cell-free } \\
\text { culture filtrate }\end{array}$ & 2000 & $4 \cdot 2$ & 1024 & 244 & $204 \cdot 9$ & $1 \cdot 0$ & 100 \\
\hline $\begin{array}{l}\text { Sephadex Fast Flow } \\
\text { (crude toxin) }\end{array}$ & 24 & $6 \cdot 5$ & 16384 & $2520 \cdot 6$ & $39 \cdot 3$ & $10 \cdot 3$ & $19 \cdot 2$ \\
\hline $\begin{array}{l}\text { FPLC Mono Q } \\
\text { anion exchange } \\
\text { chromatography } \\
\text { (purified toxin) }\end{array}$ & $3 \cdot 2$ & $2 \cdot 2$ & 4096 & $13107 \cdot 2$ & $9 \cdot 2$ & $53 \cdot 7$ & $4 \cdot 5$ \\
\hline
\end{tabular}

Table IV. Susceptibility of aeromonas toxins to temperature and enzymes

\begin{tabular}{|c|c|c|c|c|c|c|}
\hline \multirow{2}{*}{$\begin{array}{c}\text { Temperature } \\
\left({ }^{\circ} \mathrm{C}\right)\end{array}$} & \multirow{2}{*}{$\begin{array}{l}\text { Time } \\
(\mathrm{min})\end{array}$} & \multicolumn{2}{|c|}{ Activity remaining ( $\%)$} & \multirow{2}{*}{$\begin{array}{c}\text { Other } \\
\text { treatment } \\
(15 \mathrm{~min})\end{array}$} & \multicolumn{2}{|c|}{ Activity remaining (\%) } \\
\hline & & Haemolysin & Enterotoxin & & Haemolysin & Enterotoxin \\
\hline 25 & 15 & 100 & 95 & Trypsin & 100 & 96 \\
\hline 25 & 60 & 95 & 92 & $1 \mathrm{mg} / \mathrm{ml}$ & & \\
\hline 35 & 15 & 95 & 82 & Pronase & 95 & 90 \\
\hline 35 & 60 & 75 & 60 & $1 \mathrm{mg} / \mathrm{ml}$ & & \\
\hline 45 & 15 & 85 & 42 & Papain & 5 & 0 \\
\hline 45 & 60 & 20 & 27 & $1 \mathrm{mg} / \mathrm{ml}$ & & \\
\hline 55 & 15 & 5 & 0 & & & \\
\hline 55 & 60 & 0 & 0 & & & \\
\hline 65 & 15 & 0 & 0 & & & \\
\hline
\end{tabular}

a

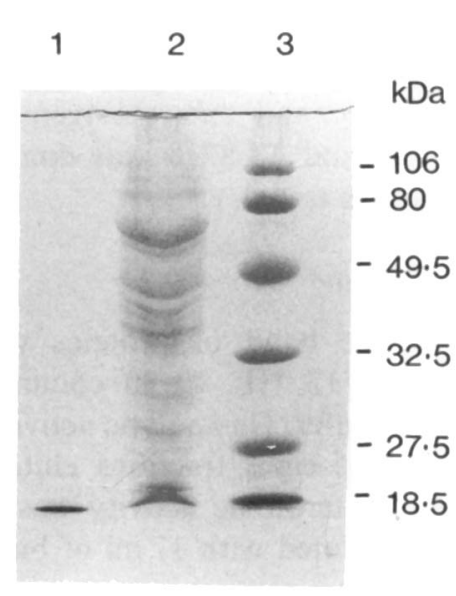

b

$\begin{array}{lll}1 & 2 & 3\end{array}$

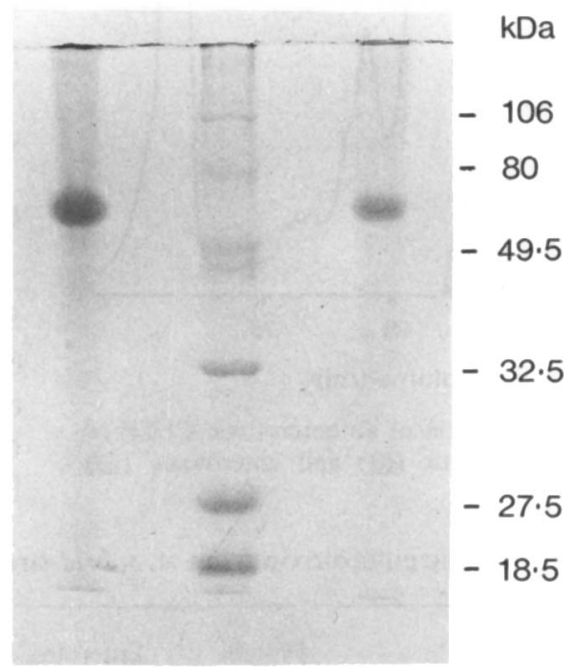

Fig. 5. SDS-PAGE of extracellular proteins of A. sobria strain YL8509 stained with Coomassie Blue. (a) Lane 1, purified cytotonic enterotoxin; 2. crude CFCF; 3, mol. wt markers. (b) Lanes 1 and 3, purified haemolysin; 2, mol. wt markers.

fraction was not distinct from the haemolytic fraction (fig. 3) when separation was attempted by this method.

\section{Anion-exchange chromatography}

Assay of each individual fraction eluting from the Mono Q HR 5/5 FPLC column for haemolytic and enterotoxic activity showed that the aeromonas $\beta$-haemolysin that caused complete haemolysis of erythrocytes was contained in a single fraction eluted with $0.17 \mathrm{M} \mathrm{NaCl}$ (fig. 4). Partial haemolysis was also detected over two broad bands. The first band eluted 
Table V. cAMP production by $\mathrm{CHO}$ tissue culture cells treated with various toxin preparations

\begin{tabular}{lcc}
\hline Treatment & $\begin{array}{c}\text { cAMP activity } \\
\text { (pmol/ml) }\end{array}$ & $\begin{array}{c}\text { Increase in } \\
\text { activity } \\
\text { (fold) }\end{array}$ \\
\hline $\begin{array}{l}\text { Tryptone soya broth } \\
\text { with 0.6\% yeast extract (control) }\end{array}$ & $1 \cdot 1$ & 1.0 \\
Cholera toxin 50 ng & 13.7 & 11.5 \\
Crude aeromonas enterotoxin & 7.5 & 5.8 \\
Purified aeromonas enterotoxin & 8.5 & 6.7 \\
Cell-free culture filtrate & 0.9 & 0 \\
of strain VL8509 & & \\
\hline
\end{tabular}

over five fractions with $0 \cdot 27-0.38 \mathrm{M} \mathrm{NaCl}$, with the peak of activity at $0.34 \mathrm{M} \mathrm{NaCl}$. The second broad band occurred over four fractions eluting with $0.42-0.51 \mathrm{M} \mathrm{NaCl}$, with the peak of activity at $0.44 \mathrm{M}$ $\mathrm{NaCl}$.

Two single fractions eluting with $0.55 \mathrm{M} \mathrm{NaCl}$ and $0.85 \mathrm{M} \mathrm{NaCl}$, respectively, caused fluid accumulation in the infant mouse test (fig. 4). The enterotoxic fractions were not haemolytic and the haemolytic fractions were not enterotoxic. The increase in specific activity and yields during toxin purification can be seen in tables II and III.

\section{Characteristics of purified toxins}

Aeromonas cytotonic enterotoxin and aeromonas $\beta$-haemolysin appeared as single bands in SDS-PAGE gels (fig. 5) with corresponding mol. wts of 15 and $55 \mathrm{kDa}$ respectively. Both were heat-labile and were inactivated at $55^{\circ} \mathrm{C}$ for $15 \mathrm{~min}$ and by papain but not by trypsin or pronase (table IV). Purified toxins did not cross-react immunologically with whole cholera toxin or the individual $A$ and $B$ subunits. The enterotoxin caused increased cAMP activity (table V) in Chinese hamster ovary tissue culture cells and was capable of binding to GM1 ganglioside to the equivalent of $7 \mathrm{ng}$ of cholera toxin (table VI).

The second, less active putative enterotoxin eluting with $0.55 \mathrm{M} \mathrm{NaCl}$ remains to be fully investigated.

\section{Discussion}

Following the emergence of detectable enterotoxin in the CFCF after incubation for $12 \mathrm{~h}$ at $37^{\circ} \mathrm{C}$, with agitation at 100 oscillations/min in tryptone soya broth supplemented with yeast extract $0.6 \%, \mathrm{pH} 7 \cdot 5$, the toxin became undetectable again just $5 \mathrm{~h}$ later. This interference with the functional activity of the toxin, probably the result of proteolytic breakdown, was accompanied by a change in the chromatographic profile of the CFCF; loss of enterotoxic activity corresponded with the appearance of a peak eluted with $0.22 \mathrm{M} \mathrm{NaCl}$. Tests for enterotoxigenicity in routine isolates should, therefore, be carried out under strictly defined conditions of $\mathrm{pH}$, temperature, agitation and time.

The infant mouse assay has been used in several studies $^{5,6,9}$ to determine the enterotoxigenic activity of Aeromonas strains but reports of the factors essential for toxin production that may determine the outcome of these assays remain scarce. Our observations agree with those of Burke et al. ${ }^{6}$ and Turnbull et al., ${ }^{9}$ who reported the importance of aeration of cultures during toxin preparation and the suitability of tryptone soya broth supplemented with yeast extract $0.6 \%$ as culture medium. We would also agree with Ljungh et al..$^{12}$ that toxin yields are higher after incubation at $37^{\circ} \mathrm{C}$ than at $20^{\circ} \mathrm{C}$, but as they used different cultural conditions and demonstrated enterotoxic activity in the rabbit ileal loop test but not in the infant mouse assay, the comparison cannot be taken further. In the present study, $\beta$-haemolysin was produced rapidly by toxigenic strains during early logarithmic growth, but we confirmed that non-toxigenic strains ${ }^{9}$ remained inactive throughout prolonged incubation and under a range of cultural conditions.

Previous attempts to separate and purify aeromonas enterotoxin from culture filtrates by diverse methodologies have failed to identify a common protein. ${ }^{12-17}$ Poor yields and the instability of purified toxins have hindered their characterisation and the functional activities of single proteins have remained poorly defined.

Table VI. Binding characteristics of aeromonas enterotoxin to GM1 ganglioside

\begin{tabular}{|c|c|c|c|}
\hline \multirow[b]{2}{*}{ Preparation } & \multicolumn{3}{|c|}{ Ganglioside GM1 binding assay } \\
\hline & $\begin{array}{c}\text { Absorbance } \\
\left(\mathrm{A}_{410}\right)\end{array}$ & $\begin{array}{c}\text { Estimated cholera } \\
\text { toxin } \\
\text { equivalent* } \\
(\mathrm{ng} / \mathrm{ml})\end{array}$ & $\begin{array}{l}\text { Enterotoxicity } \\
\text { in infant mouse } \\
\text { (IW/BW ratio) }\end{array}$ \\
\hline Crude aeromonas enterotoxin & $0 \cdot 18$ & $5 \cdot 8$ & 0.0914 \\
\hline Crude aeromonas haemolysin & 0.01 & 0.0 & 0.0677 \\
\hline Purified aeromonas enterotoxin & $0 \cdot 23$ & $7 \cdot 0$ & 0.0956 \\
\hline Purified aeromonas haemolysin & 0.02 & $0 \cdot 0$ & 0.062 \\
\hline Cholera toxin $50 \mathrm{ng}$ & $1 \cdot 62$ & $50 \cdot 0$ & NT \\
\hline $\begin{array}{l}\text { Tryptone soya broth } \\
\text { with } 0.6 \% \text { yeast extract }\end{array}$ & $0 \cdot 01$ & 0.0 & $0-0529$ \\
\hline
\end{tabular}


More than one functional activity, including enterotoxicity and haemolysis of erythrocytes have been assigned previously to single proteins ${ }^{13-15}$ but we found no evidence of this in the present study. The 55-kDa $\beta$ haemolysin described herein caused no fluid accumulation in the infant mouse assay and the existence of haemolytic activity in the CFCF did not correspond with either the emergence or decline of enterotoxic activity. In view of reports describing haemolytic enterotoxin, ${ }^{13-15}$ more than one type of aeromonas $\beta$ haemolysin may exist, and recent reports have indicated that several different antigenic types of haemolysin may occur. ${ }^{18}$

Purified aeromonas cytotonic enterotoxin proved to be similar in size $(15 \mathrm{kDa})$, to an active protein

\section{References}

1. Lautrop H. Aeromonas hydrophila isolated from human faeces and its possible pathological significance. Acta Pathol Microbiol Scand 1961; 144 : 299-301.

2. Cumberbatch N, Gurwith MJ, Langston C, Sack RB, Brunton JL. Cytotoxic enterotoxin produced by Aeromonas hydrophila: relationship of toxigenic isolates to diarrhoeal disease. Infect Immun 1979; 23: 829-837.

3. Gracey M, Burke V, Robinson J. Aeromonas-associated gastroenteritis. Lancet 1982; 2: 1304-1306.

4. Agger WA, McCormick JD, Gurwith MJ. Clinical and microbiological features of Aeromonas hydrophila-associated diarrhoea. J Clin Microbiol 1985; 21 : 909-913.

5. Burke V, Gracey M, Robinson J, Peck D, Beaman J, Bundell C. The microbiology of childhood gastroenteritis: Aeromonas species and other infectious agents. $J$ Infect Dis $1983 ; 148$ : 68-74.

6. Burke V, Robinson J, Berry RJ, Gracey M. Detection of enterotoxins of Aeromonas hydrophila by a suckling mouse test. J Med Microbiol $1981 ; 14: 401-408$.

7. Ljungh A. Aeromonas-toxins and other virulence factors. Proceedings of the 1st International Workshop on Aeromonas and Plesiomonas, Manchester. 1986: 33-35.

8. Morgan DR, Johnson PC, DuPont HL, Satterwhite TK, Wood LV. Lack of correlation between known virulence properties of Aeromonas hydrophila and enteropathogenicity for humans. Infect Immun 1985; 50: 62-65.

9. Turnbull PCB, Lee JV, Miliotis MD et al. Enterotoxin production in relation to taxonomic grouping and source of isolation of Aeromonas species. J Clin Microbiol 1984; 2: 175-180. described by Ljungh et al. ${ }^{12}$ Its ability to stimulate cAMP production was demonstrated and, although it displayed some ability to bind to GMl ganglioside, it did not cross-react immunologically with whole cholera toxin or cholera toxin subunits $\mathrm{A}$ and $\mathrm{B}$. It is suggested, therefore, that aeromonas cytotonic enterotoxin is a unique toxin which, in view of its molecular size, is unlikely to be divisible into subunits.

In addition to the $15 \mathrm{kDa}$ enterotoxin a second enterotoxic fraction was eluted with $0.55 \mathrm{M} \mathrm{NaCl}$. This fraction was also non-haemolytic and was immunologically distinct from the first enterotoxin and the haemolysin. Attempts to purify and characterise the second cytotonic enterotoxin are in progress.

10. Elliott RP, Clark DS, Lewis KH, Lundbeck H, Olson JC, Simonsen B (eds). Enumeration of mesophilic aerobes. In: Micro-organisms in foods. University of Toronto Press, ICMSF. 1978: 119-120.

11. Laemmli UK. Cleavage of structural proteins during the assembly of the head of the bacteriophage T4. Nature $1970 ; 227: 680-685$.

12. Ljungh $A$, Eneroth $P$, Wadstrom T. Cytotonic enterotoxin from Aeromonas hydrophila. Toxicon 1982; 20 : 787-794.

13. Rose JM, Houston CW, Coppenhaver DH, Dixon JD, Kurosky A. Purification and chemical characterisation of a cholera toxin-cross-reactive cytolytic enterotoxin purified from a human isolate of Aeromonas hydrophila. Infect Immun 1989; 57 : 1165-1169.

14. Asao T, Kinoshita Y, Kosaki S, Uemura T, Sakaguchi G. Purification and some properties of Aeromonas hydrophila hemolysin. Infect Immun 1984; 46: 122-127.

15. Potomski J, Burke V, Watson I, Gracey M. Purification of cytotoxic enterotoxin of Aeromonas sobria by use of monoclonal antibodies. $J$ Med Microbiol 1987; 23: 171177.

16. Chakraborty T, Montenegro MA, Sanyal SC, Helmuth R, Bulling E, Timmis KN. Cloning of enterotoxin gene from Aeromonas hydrophila provides conclusive evidence of production of a cytotonic enterotoxin. Infect Immun 1984; 46: 435-441.

17. Potomski J, Burke V, Robinson J, Fumarola D, Miragliotta G. Aeromonas cytotonic enterotoxin cross-reactive with cholera toxin. J Med Microbiol 1987; 23 : 179-186.

18. Chopra AK, Houston CW, Kurosky A. Genetic variation in related cytolytic toxins produced by different species of Aeromonas. FEMS Microbiol Lett 1991; 62: 231-237. 